doi: $10.15407 /$ ujpe60.09.0975

O.P. RUDENKO

Poltava V.G. Korolenko National Pedagogical University

(2, Ostrograds'kyi Str., Poltava 36000, Ukraine)

\title{
SOME WORDS ABOUT MY FELLOW TOWNSMAN
}

More than 40 years ago, I got acquainted with Leonid Anatoliyovych at the Chair of Molecular Physics of the Taras Shevchenko Kyiv State University. The chair was headed at that time by Prof. O.Z. Golyk. We two were still young, full of energy and strength: he was an assistant at the chair, and I was a postgraduate student, a graduate from the Faculty of Physics and Mathematics of the Poltava Pedagogical Institute. The team at the Chair of Molecular Physics met me benevolently and with kind attention. Leonid Anatoliyovych turned out to be my fellow townsman from Poltava! This made us closer. Long years of our communication transformed into warn friendly relations. I was glad to be acquainted with his father Anatolii Vasylyovych, who was a driver of steam locomotives, and his mother Olena Fominichna, a pharmacist. They were beautiful and respectable persons, whom I respected very much.

My acquaintance with Leonid Anatoliyovych transformed into a long-term friendship, and the cooperation between the Chair of Molecular Physics at the Kyiv University and the Chair of General Physics at the Poltava Pedagogical Institute into a scientific community. Time passed quickly. In 1989, Leonid Anatoliyovych became the Dr. Sci. in physics and mathematics. We simultaneously occupied the dean positions at the corresponding faculties. It is a post that obliged everybody to be both a teacher and a scientist.

The pedagogical activity of L.A. Bulavin was inseparable from his scientific creativity. He lectured, developed programs of new courses, wrote textbooks in molecular physics, and headed the Chair. The edu-

(C) O.P. RUDENKO, 2015

ISSN 2071-0194. Ukr. J. Phys. 2015. Vol. 60, No. 9 cational activity of L.A. Bulavin is based on the principles of cooperation and co-authorship with the student youth under the motto "Do as I do, do better than me".

A specific feature of the scientific activity of Leonid Anatoliyovych is the formulation and solution of the problems that are challenging for physics, as well as their practical application. As an example, it may be a training of experts in medical physics at the Taras Shevchenko National University of Kyiv, at the Chair of Molecular Physics, in the speciality "Medical physics". This branch of physics uses almost all domains of modern fundamental physics, with the molecular physics being probably at the first place.

As the Dean of the Faculty of Physics and the head of the Chair of Molecular Physics, Leonid Anatoliyovych was an initiator of the physical contests for the entrants to the Faculty of Physics of the Taras Shevchenko National University of Kyiv. The winners of those competitions gained the opportunity to enter the Faculty of Physics without passing the entrance examinations. Later, such contests were started to be held almost at all faculties of the Kyiv University. L.A. Bulavin became a founder of the International scientific conference, which is held every two years, and the tireless Leonid Anatoliyovych is the Chairman of its organizing committee.

The scientific interests of Leonid Anatoliyovych Bulavin - now, the Dr. Sci. in physics and mathematics, Professor, and Academician - are distinguished by their variety. He is known as an outstanding Ukrainian scientist in physics of fluids, physics of phase transformations and critical phenomena, neutron spectroscopy of condensed systems, medical physics, and nanophysics. At the chair, he created 
a scientific school of neutron spectroscopy of condensed media. Under the supervision of Leonid Anatoliyovych, 15 Doctoral and 33 Ph.D. theses were defended. His disciples work in Ukraine, France, Russia, the USA, Belgium, Hungary, and Germany. He is the author of 300 scientific papers in professional journals; 73 of them were written in the co-authorship with scientists from 19 countries.

Leonid Anatoliyovych is an extremely active person. He is the head of the chair, the chairman of the scientific and methodological council in physics of the Ministry of Education and Science of Ukraine, the Editor-in-Chief of the collection of papers "Physics of Liquid State", the associate editor of the "Ukrainian Journal of Physics" and the journals "Nuclear Physics and Power Engineering", "Reports of the National Academy of Sciences of Ukraine", "Safety Problems of Atomic Power Plants and Chornobyl", and "Physics and Chemistry of Solids". He is a member of the Ukrainian and American Physical Societies. L.A. Bulavin is the Soros Professor. He develops and maintains the relations with many scientific institutions of the NAS of Ukraine, scientific labo- ratories in the European countries, and educational institutions in Ukraine.

Thirty textbooks and monographs published in Ukraine, Russia, the USA, and Germany confirm the importance of the scientific results obtained by him.

Our meetings in our homeland, in our native Poltava, unite us not only as scientists, but also as close friends. In heart-to-heart conversations, new conferences, the results of researches by post-graduate students, new articles, students' contests, and so on are planned and determined imperceptibly; ... as well as which physical mechanisms are responsible for the behavior of viscosity in that or another system.

Leonid Anatoliyovych Bulavin meets his anniversary at the peak of vital and creative capabilities. Being a scientist, a teacher, a patriot, as well as a strong, purposeful, and well-organized Person, powerful in scientific, pedagogical, public, and human sense, he creates new scientific ideas and projects, cherishes the qualitative staff of Ukrainian scientists, and is sick at heart for Ukraine, for its present and future.

Received 11.06.15.

Translated from Ukrainian by O.I. Voitenko 